Article

\title{
RELATIONSHIP BETWEEN SOIL SEED BANK AND CANOPY COVERAGE IN A MINED AREA
}

\author{
Diego Balestrin $^{2 *} \odot$, Sebastião Venâncio Martins ${ }^{3} \odot$,Wesley Fonseca ${ }^{4} \odot$, Luiz Henrique Elias Cosimo $^{4}$
}

${ }^{1}$ Received on 06.06.2018 accepted for publication on 29.03.2019.

${ }^{2}$ Universidade Federal de Viçosa, doutor em Ciência Florestal, Viçosa, MG - Brasil. E-mail: <diegobalestrin@hotmail.com>.

${ }^{3}$ Universidade Federal de Viçosa, Departamento de Engenharia Florestal, Viçosa, MG - Brasil. E-mail: <venancioufv@gmail.com>.

${ }^{4}$ Universidade Federal de Viçosa, Programa de Pós-Graduação em Ciência Florestal, Viçosa, MG - Brasil. E-mail: <wesleyfonseca27@ gmail.com> and <luizhenriquecosimo@gmail.com>.

*Corresponding author.

\begin{abstract}
The objective of this study was to evaluate and correlate information about soil seed bank and canopy (\%Canopy Openness and Leaf area index-LAI) in a mined area in restoration process through natural regeneration. The study area is located in Zona da Mata of Minas Gerais, which presents predominance of Semideciduous Seasonal Forest, and has an area of 0.5 ha in process of natural regeneration after six years of bauxite exploitation (without any intervention). Along the area, ten plots of $45 \times 29 \mathrm{~cm}$ were allocated and distributed in the best way to represent the whole area in restoration process. Seed bank diversity and canopy characteristics were evaluated in these plots, the last one using a NIKON D40X photographic camera, with fisheye lens of $8 \mathrm{~mm}$. As results, 8280 individuals (tree, shrub, herbs, and vines) were found, totaling 51 species and 24 botanical families. The Shannon diversity index (H') was 2.770 , and the equability (J) was 0.705 , which demonstrate an average diversity in this area, with a density of 2114.94 germinated seeds $\mathrm{m}^{-2}$. Through the evaluation of the seed bank, the presence of exotic species $(23.5 \%)$, the dominance of the pioneer species $(68.6 \%)$, as well as high dispersal by wind $(52.9 \%)$ were verified in the area. According to canopy characteristics, a significant variation between different points/regions within the study area was found, while patterns of existence of certain herbs as a function of canopy openness (lower vegetal cover/clearings) were also identified, as well as in response to spatial proximity between the allocated plots, confirming the high correlation between these two variables and their importance in the process of forest restoration.
\end{abstract}

Keywords: Mining; Restoration of degraded areas; Natural regeneration.

\section{BANCO DE SEMENTES DO SOLO E SUA RELAÇÃO COM O DOSSEL EM UMA ÁREA MINERADA}

RESUMO - Os objetivos deste estudo foram avaliar e correlacionar dados do banco de sementes do solo e do dossel (abertura de dossel-\% Canopy Openness e índice de área foliar-IAF) em uma área minerada em processo de restauração por regeneração natural. A área de estudo localiza-se na Zona da Mata Mineira, que apresenta predomínio de Florestas Estacionais Semideciduais, e possui área de 0.50 ha em processo de regeneração natural após 6 anos da exploração de bauxita (sem nenhuma intervenção). Foram plotadas 10 parcelas de $45 \times 29 \mathrm{~cm}$ ao longo da área, distribuidas de forma a representar toda a porção em processo de restauração. Nestas parcelas foram avaliadas a diversidade do banco de sementes e as características de dossel, estas últimas coletadas através de uma câmera fotográfica NIKON D4OX com lente de $8 \mathrm{~mm}$ (fisheye). Como resultados foram encontrados 8.280 individuos arbóreos, arbustivos, herbáceos e trepadeiras, totalizando 51 espécies e 24 famílias botânicas. O indice de diversidade de Shannon (H') foi 2,770 e a equabilidade (J) foi 0,705, demonstrando assim uma média diversidade florística desta área, com densidade de 2.114,94 sementes germinadas $m^{-2}$. Através da análise do banco de sementes verificou-se a presença de espécies exóticas na área (23,5\%), domínio de espécies pioneiras (68,6\%), assim como a predominância de espécies dispersas por anemocoria $(52,9 \%)$. Quanto às características do dossel, verificou-se uma grande variação existente em diferentes pontos da área, podendo também ser identificado certos padrões de existência de determinadas 
espécies herbáceas em função da abertura do dossel (menor cobertura vegetal/clareiras), bem como em função da proximidade espacial entre as parcelas plotadas, comprovando assim a alta correlação entre estas duas variáveis e sua importância no processo de restauração florestal.

Palavras-chave: Mineração; Recuperação de áreas degradadas; Regeneração natural.

\section{INTRODUCTION}

A better understanding of the dynamics, behavior, and existence of establishment patterns in response to environmental and local characteristics is essential for the definition, development, and execution of ecological restoration projects (Martins, 2018a). In this sense, there are different ways, methods, and indicators to evaluate a degraded environment or one that has undergone some alterations on its vegetable, edaphic, and fauna levels, among others.

Natural regeneration is one of the most commonly used vegetative indicators, which is the result of a set of ecological processes and components of the ecosystem (seed rain, seed bank, regrowth of roots and strains). Thus, it expresses the resilience of the recovering ecosystem (Martins, 2018a). However, other indicators can also be applied, such as litter production and decomposition and canopy openness, which influence directly the local microclimate and species adaptation in response to the tolerance to solar incidence (Martins et al., 2008; Martins, 2009).

In this sense, the soil seed bank, which is composed of viable non-germinated seeds present in the soil or mixed with the litter (Simpson et al., 1989), is an important source of propagules for the plant restoration of an altered site (Lu et al., 2010). Also, it helps to understand the mechanisms of adaptation, distribution, and viability of plant species in a given area (Ooi, 2012).

Furthermore, soil seed bank assessment enables to "predict" the responses of a forest in case some disturbance occurs in the area (Cumming et al., 2005; Coutts et al., 2011; Martins et al., 2015); moreover, its use in altered areas allows the increase of plant diversity (e.,g seed bank transposition), re-establishment of native species on the area (Hall et al., 2010), as well as the identification of possible relationships or effects of the canopy vegetation on seed bank dynamics (Hyatt and Casper, 2001), among other possibilities.

Thus, vegetative indicators have a high potential for utilization because they are easy to be quantified when compared with other biological indicators. In addition to these indicators, canopy openness (\%Cnpy Open) and leaf area index (LAI) can be used to evaluate the structure and characteristics of the canopy (Woodgate W et al., 2015), which directly influence the internal microclimate of the forest (Gaudio et al., 2012; Von Arx et al, 2017), the amount of intercepted radiation (Chianucci and Cutini., 2013; Jagodzínski et al., 2016) and the adaptation of certain species (Matlaga et al., 2017; Song et al., 2018).

Moreover, the assessment of the canopy features assists in modeling canopy environmental characteristics (Macfarlane et al., 2000; Leblanc and Chen, 2001), which are fundamental for a better understanding of existing interrelationships as well as the quantification of impacts in the area. Thus, since LAI is related to the production of plant biomass/ litter and is a good indicator of canopy structure and architecture, this index is an important parameter in the evaluation of forest stands. Hence, it is a good indicator of the development and evolution of the area (Linhares et al., 2000; Villa Nova et al., 2003; Xavier and Vettorazzi, 2003).

This evaluation is necessary because in the canopy there are several processes that directly or indirectly are essential in the process of development of a particular ecosystem, including transpiration, photosynthesis, and supply of organic matter for nutrient cycling. Thus, especially in altered areas, it is necessary to carry out evaluations and monitoring to avoid the occurrence of unforeseen events that may impair the desired restoration.

In this sense, the objective of this study was to correlate canopy openness and leaf area index data

Revista Árvore 2019;43(4):e430403 
with the information of the seed bank found in the litter of a mined area to identify plant establishment and development patterns with canopy characteristics of an area undergoing natural regeneration after bauxite mining.

\section{MATERIAL AND METHODS}

This study was conducted in a post-bauxite mining area located at the coordinates $21^{\circ} 01^{\prime} 58.82^{\prime \prime}$ S and $42^{\circ} 34^{\prime} 59.82^{\prime} \mathrm{W}$, in the municipality of São Sebastião da Vargem Alegre, in the Forest Zone (Zona da Mata) in the state of Minas Gerais, Brazil (Figure 1). The area has 0.5 ha and was exploited by the Brazilian Aluminum Company (CBA) in 2009 and 2010

Prior to the mining process, this area was used for coffee growing and historically by livestock (pasture). After the mining process, the area was topographically reconfigured, and the overburden was covered with a $50 \mathrm{~cm}$ topsoil layer. Afterwards, this area was selected for the use of the natural regeneration technique, and then the canopy and seed bank characteristics were evaluated six years after mineral exploration.

Inserted in the Atlantic Forest Biome, this area presents a climate classified as Aw, tropical with dry winter (Köppen, 1948). The average annual temperature is $18.2^{\circ} \mathrm{C}$, with an average yearly rainfall of $1,564 \mathrm{~mm}$, rainy season from November to April and a dry season from May to October (Agevap, 2013).

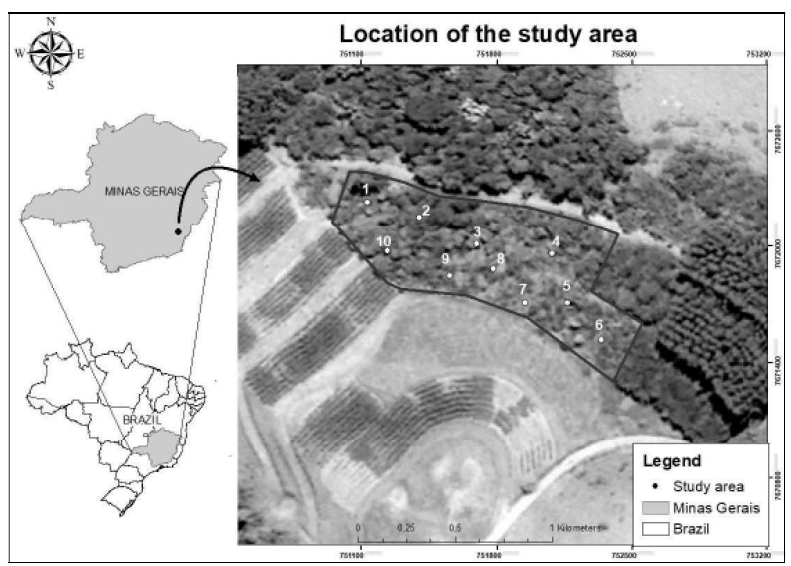

Figure 1 - Study area location (highlighted).

Figura 1 - Localização da área de estudo (em destaque).
According to the Brazilian Soil Classification System (Embrapa, 2013), typical dystrophic RedYellow Latosol soils predominate in the region, with typical vegetation classified as Semideciduous Seasonal Montane Forest (IBGE, 2012). The study area is within a landscape composed by pastures, forest plantations (mainly Corymbia spp.), native forest fragments, agricultural areas and recovering areas at different stages and ages, as well as areas under mining by the company.

In order to analyze canopy openness (\%Cnpy Open) and leaf area index (LAI) characteristics, ten sampling points were determined to represent the area as best as possible. In addition, a minimum distance of 10 meters between the sampling points (plots) and from the edge was considered.

A digital camera NIKON D40X with fisheye lens of $8 \mathrm{~mm}$ was used to obtain the canopy information, providing a $180^{\circ}$ aperture. One image per point was acquired, all at 1.30 meters from the ground, thus totaling ten images for further processing.

It is worth mentioning that the readings were performed only when there was diffused light, which were recorded in the morning, between 7 h00 and 10 h00 a.m., avoiding periods of high incidence of solar radiation. Subsequently, the images were analyzed and classified using the Gap Light Analyzer 2.0 software (Frazer et al., 1999) to calculate the measurements.

Three samples of the topsoil to a depth of 5.0 $\mathrm{cm}$ were also collected at each point where canopy images were taken, with the aid of a $45 \times 29 \mathrm{~cm}(1,305$ $\mathrm{cm}^{2}$ ) frame, totaling 30 samples. These samples were transported to the shade house of the Research Nursery at Universidade Federal de Viçosa and stored in plastic trays $(0.45 \times 0.29 \times 0.08 \mathrm{~m})$, under sprinkler irrigation and isolated from possible contamination by external propagules.

Subsequently, these samples were evaluated biweekly over a 9-month period, and all emerging seedlings in each evaluation (regardless of life form) were counted and identified. The Fitopac 2.1 software (Shepherd, 2010) was used to evaluate the phytosociological parameters of the seed bank contained in the soil of the area.

In addition, the canonical correlation analysis (CCA) between the environmental variables (canopy

\section{silf}

Revista Árvore 2019;43(4):e430403 
characteristics) and the plant variables (seed bank) was carried out with the R software (R CORE TEAM, 2016), using the Vegan package (Oksanen et al., 2016). Also, the significance level was evaluated through the Monte Carlo permutation test (Ter Braak and Prentice, 1988).

\section{RESULTS}

The list of species and their families found in each plot through the evaluation of the seed bank in the litter of the study area is shown in Table 1 . The species with the largest number of individuals were the following: Phyllanthus tenellus Roxb. (2,001); Ageratum conyzoides L. (1,216); Amaranthus deflexus L. (858); Oxalis corniculata L. (691) and Trema micrantha (L.) Blume (397), which represented a relative density of $24.17 \% ; 14.69 \% ; 10.36 \% ; 8.35 \%$ and $4.79 \%$, respectively.

A total of 8,280 individuals, 51 species and 24 botanical families were found, with the Shannon diversity index ( $\left.\mathrm{H}^{\prime}\right)$ of 2.770 and equability $(\mathrm{J})$ of 0.705 . Besides, the density of seedlings contained in the seed bank of the area was 2,114.94 individuals $\mathrm{m}^{-2}$.

Regarding the characteristics of the life forms (LF) of the species found in the seed bank of the collected samples, it was verified the presence of $68.6 \%$ of herbaceous species $(71.4 \%$ native and $28.5 \%$ exotic), $13.7 \%$ of tree species (100\% native), $9.8 \%$ of shrub (60\% native and $40 \%$ exotic), $2 \%$ of vines (100\% native) and $5.9 \%$ were not classified. Out of the total individuals identified, $23.5 \%$ were considered exotic, $70.6 \%$ native to the region, and $5.9 \%$ were not classified.

Concerning the successional category of species found in the seed bank in the study area, it was observed the predominance of pioneer species $(68.6 \%)$, out of which $71.4 \%$ were herbaceous; $14.2 \%$ trees, $11.4 \%$ shrubs, and 3\% not classified. In addition, regarding dispersal syndrome, most species showed dispersal by anemochory (52.9\%), followed by zoochory (23.5\%). In this context, the tree species Euterpe edulis Mart.; Trema micrantha (L.) Blume; Senna multijuga (Rich.) H.S. Irwin \& Barneby; Solanum mauritianum Scop and Cecropia hololeuca stand out since they stimulate the forest restoration process either by high adaptation to restrictive environmental conditions or by dispersal and its relationship with the local fauna, thus facilitating the successional advancement of the area.

Regarding the results generated by the canopy evaluation, the \%Cnpy Open and LAI values were generated for each point, as shown in Table 2. It is important to mention that plot 7 was visually dominated by invasive grasses, which consequently influenced the growth, development, and succession of shrub and tree species in this plot and their surroundings, thus explaining the high canopy opening values found in this area.

As for the correlation analysis between canopy data (\% Cnpv Open and LAI) and area seed bank (species richness), the ordering diagram was generated (Figure 2), where CCA explained $27.55 \%$ of the total inertia. From this value, axis 1 accounted for $85.39 \%$ and axis 2 for $14.61 \%$ of the explanation produced. Also, a high correlation of LAI with the species Emilia sonchifolia (L.) DC and Urochloa plantaginea (Link) R.D. Webster was observed (highlighted).

A particular trend can also be observed in the establishment of some plant species in response to the plot or the spatial location in the study area. Such pattern can also be seen through the evaluation of the amount of seeds found per plot, which showed higher density in plots 4,5 and 6 , with values of $1,150,1,857$ and 1,132 , respectively, where herbaceous species (such as grasses) had a significant participation in the results.

In addition, the highest LAI values, which reflect the highest values of the forest canopy cover, were found in plots 9, 10 and 8 respectively, not representing, however, the highest seed concentrations found in the seed bank.

Regarding the participation in the floristic composition of certain grass species, it can be observed in plot 7 (area that visually presented dominance of invasive grasses and low canopy cover), that the seed bank formed had dominance of shrub and herbaceous species such as Ageratum conyzoides L.; Amaranthus deflexus L.; Phyllanthus tenellus Roxb and Rubus rosifolius $\mathrm{Sm}$., which accounted for $32.8 \%$; 29.2\%; $18.5 \%$ and $9.5 \%$ of the total species found in this plot, respectively. Thus, it can be inferred that the dominance of grasses is hindering the spontaneous regeneration of vegetation and the advancement of the ecological succession of this area.

Revista Árvore 2019;43(4):e430403 
Table 1 - Vegetal species and their respective botanical families which were found in each plot in the study area.

Tabela 1 - Espécies vegetais e suas respectivas famílias botânicas encontradas em cada parcela na área de estudo.

\begin{tabular}{|c|c|c|c|c|c|c|c|c|c|c|c|c|c|c|}
\hline \multirow[t]{2}{*}{ Family/species } & \multicolumn{10}{|c|}{ Plots } & \multirow[t]{2}{*}{$\overline{\mathrm{LF}}$} & \multirow[t]{2}{*}{$\overline{\mathrm{OR}}$} & \multirow[t]{2}{*}{$\mathrm{SC}$} & \multirow[t]{2}{*}{ DS } \\
\hline & 1 & 2 & 3 & 4 & 5 & 6 & 7 & 8 & 9 & 10 & & & & \\
\hline \multicolumn{15}{|l|}{ Amaranthaceae } \\
\hline $\begin{array}{l}\text { Amaranthus deflexus L. } \\
\text { Arecaceae }\end{array}$ & 36 & 5 & 23 & 28 & 170 & 442 & 153 & & 1 & & $\mathrm{H}$ & $\mathrm{E}$ & $\mathrm{Pi}$ & Zoo \\
\hline Euterpe edulis Mart. & & & & & & & & 4 & & & $\mathrm{~T}$ & $\mathrm{~N}$ & LS & Zoo \\
\hline \multicolumn{15}{|l|}{ Asteraceae } \\
\hline Erechtites hieraciifolius (L.) Raf. ex DC. & & & 1 & & 1 & 2 & & & & & $\mathrm{H}$ & $\mathrm{N}$ & $\mathrm{Pi}$ & Ane \\
\hline Ageratum conyzoides L. & 115 & 159 & 127 & 126 & 98 & 129 & 172 & 88 & 79 & 123 & $\mathrm{H}$ & $\mathrm{N}$ & $\mathrm{Pi}$ & Zoo \\
\hline Conyza canadensis (L.) Cronquist & 11 & 15 & 18 & 21 & 31 & 33 & 17 & 17 & 33 & 17 & $\mathrm{H}$ & $\mathrm{E}$ & $\mathrm{Pi}$ & Ane \\
\hline Emilia sonchifolia (L.) DC. & & 3 & & & & & & & 3 & 3 & $\mathrm{H}$ & $\mathrm{N}$ & $\mathrm{Nc}$ & Ane \\
\hline Galinsoga parviflora Cav. & 3 & 1 & 2 & 1 & 15 & 9 & 6 & & 25 & 1 & $\mathrm{H}$ & $\mathrm{E}$ & $\mathrm{Pi}$ & Ane \\
\hline Galinsoga quadriradiata Ruiz \& Pav. & & & & 12 & & 3 & & & & & $\mathrm{H}$ & $\mathrm{E}$ & $\mathrm{Pi}$ & Ane \\
\hline Gnaphalium pensylvanicum Willd & & 4 & 5 & & 2 & 2 & 1 & 6 & & & $\mathrm{H}$ & $\mathrm{N}$ & ES & Ane \\
\hline Gnaphalium purpureum L. & 32 & & 2 & 4 & & 11 & & & & 2 & $\mathrm{H}$ & $\mathrm{N}$ & ES & Ane \\
\hline Gnaphalium spicatum Mill. & 1 & 1 & 1 & 4 & 15 & & & & & & $\mathrm{H}$ & $\mathrm{N}$ & ES & Ane \\
\hline Sonchus oleraceus L. & & 2 & & & & 3 & & & 3 & & $\mathrm{H}$ & $\mathrm{N}$ & $\mathrm{Pi}$ & Ane \\
\hline Vernonanthura diffusa (Less.) H. Rob. & 8 & 9 & 12 & 5 & 12 & 15 & 15 & & 6 & 32 & $\mathrm{~T}$ & $\mathrm{~N}$ & $\mathrm{Pi}$ & Ane \\
\hline \multicolumn{15}{|l|}{ Begoniaceae } \\
\hline Begonia cucullata Willd. & & & & & & & & 70 & & & $\mathrm{H}$ & $\mathrm{N}$ & $\mathrm{Pi}$ & Ane \\
\hline \multicolumn{15}{|l|}{ Brassicaceae } \\
\hline Lepidium virginicum $\mathrm{L}$. & 5 & 6 & 8 & 21 & 10 & 25 & 8 & 1 & 10 & 9 & $\mathrm{H}$ & $\mathrm{E}$ & $\mathrm{Pi}$ & $\mathrm{Nc}$ \\
\hline \multicolumn{15}{|l|}{ Cannabaceae } \\
\hline Trema micrantha (L.) Blume & 9 & 26 & 5 & & 10 & & & 3 & 121 & 223 & $\mathrm{~T}$ & $\mathrm{~N}$ & $\mathrm{Pi}$ & Zoo \\
\hline \multicolumn{15}{|l|}{ Commelinaceae } \\
\hline Commelina benghalensis L. & 2 & & & 31 & 26 & 3 & & & 2 & 3 & $\mathrm{H}$ & $\mathrm{N}$ & $\mathrm{Pi}$ & Aut \\
\hline Commelina diffusa Burm. f. & 1 & & & 9 & 6 & 1 & & & & & $\mathrm{H}$ & $\mathrm{N}$ & $\mathrm{Pi}$ & Aut \\
\hline \multicolumn{15}{|l|}{ Convolvulaceae } \\
\hline Ipomoea $\mathrm{sp}$. & 15 & 7 & 2 & 100 & 82 & 61 & 10 & & 7 & 5 & V & $\mathrm{N}$ & $\mathrm{Pi}$ & Ane \\
\hline \multicolumn{15}{|l|}{ Cyperaceae } \\
\hline Cyperus distans L. f. & & & & 3 & & & & & & & $\mathrm{H}$ & $\mathrm{N}$ & $\mathrm{Pi}$ & Ane \\
\hline Cyperus rotundus L. & 36 & 29 & 18 & 23 & 77 & 20 & 11 & & 9 & 2 & $\mathrm{H}$ & $\mathrm{N}$ & $\mathrm{Pi}$ & Ane \\
\hline \multicolumn{15}{|l|}{ Euphorbiaceae } \\
\hline Euphorbia heterophylla L. & & & & & 2 & & & & & & $\mathrm{H}$ & $\mathrm{N}$ & $\mathrm{Pi}$ & Aut \\
\hline \multicolumn{15}{|l|}{ Fabaceae } \\
\hline $\begin{array}{l}\text { Senna multijuga (Rich.) H.S. Irwin \& Barne } \\
\text { Aut }\end{array}$ & & 4 & 4 & 4 & & & 1 & 1 & 2 & 2 & & $\mathrm{~T}$ & $\mathrm{~N}$ & ES \\
\hline Lamiaceae & & & & & & & & & & & & & & \\
\hline Hyptis suaveolens (L.) Poit. & 3 & 3 & 8 & 13 & 37 & 22 & 17 & 4 & 9 & 7 & $\mathrm{H}$ & $\mathrm{N}$ & $\mathrm{Pi}$ & Zoo \\
\hline Leonotis nepetifolia (L.) R. Br. & 32 & & & 84 & 16 & 10 & & & & & $\mathrm{~S}$ & $\mathrm{E}$ & $\mathrm{Pi}$ & Ane \\
\hline Malvaceae & & & & & & & & & & & & & & \\
\hline Sida rhombifolia L. & 34 & 7 & 24 & 59 & 21 & 48 & 27 & 10 & 23 & 19 & $\mathrm{H}$ & $\mathrm{N}$ & $\mathrm{Pi}$ & Ane \\
\hline Triumfetta rhomboidea Jacq. & & 2 & & 9 & & 1 & & & & & $\mathrm{~S}$ & $\mathrm{E}$ & $\mathrm{Pi}$ & Zoo \\
\hline Melastomataceae & & & & & & & & & & & & & & \\
\hline Leandra niangaeformis Cogn. & 1 & & & & 1 & 3 & 3 & 5 & 5 & 24 & $\mathrm{~S}$ & $\mathrm{~N}$ & $\mathrm{Pi}$ & Zoo \\
\hline Onagraceae & & & & & & & & & & & & & & \\
\hline Ludwigia tomentosa (Cambess.) H. Hara & & 8 & & & 9 & 13 & 4 & 11 & 4 & & $\mathrm{~S}$ & $\mathrm{~N}$ & $\mathrm{Pi}$ & Ane \\
\hline Oxalidaceae & & & & & & & & & & & & & & \\
\hline Oxalis corniculata $\mathrm{L}$. & 71 & 81 & 18 & 167 & 258 & 42 & 30 & 3 & 11 & 10 & $\mathrm{H}$ & $\mathrm{E}$ & $\mathrm{Nc}$ & Ane \\
\hline Phyllanthaceae & & & & & & & & & & & & & & \\
\hline Phyllanthus tenellus Roxb. & 155 & 253 & 80 & 311 & 733 & 126 & 97 & 15 & 108 & 123 & $\mathrm{H}$ & $\mathrm{N}$ & ES & Aut \\
\hline
\end{tabular}


Table 1...

Tabela $1 .$.

\begin{tabular}{|c|c|c|c|c|c|c|c|c|c|c|c|c|c|c|}
\hline \multirow[t]{2}{*}{ Family/species } & \multicolumn{10}{|c|}{ Plots } & \multirow[t]{2}{*}{ LF } & \multirow[t]{2}{*}{ OR } & \multirow{2}{*}{\multicolumn{2}{|c|}{$\mathrm{SC} \quad \mathrm{DS}$}} \\
\hline & 1 & 2 & 3 & 4 & 5 & 6 & 7 & 8 & 9 & 10 & & & & \\
\hline \multicolumn{15}{|l|}{ Amaranthaceae } \\
\hline $\begin{array}{l}\text { Amaranthus deflexus L. } \\
\text { Arecaceae }\end{array}$ & 36 & 5 & 23 & 28 & 170 & 442 & 153 & & 1 & & $\mathrm{H}$ & $\mathrm{E}$ & $\mathrm{Pi}$ & Zoo \\
\hline Euterpe edulis Mart. & & & & & & & & 4 & & & $\mathrm{~T}$ & $\mathrm{~N}$ & LS & Zoo \\
\hline \multicolumn{15}{|l|}{ Asteraceae } \\
\hline Erechtites hieraciifolius (L.) Raf. ex DC. & & & 1 & & 1 & 2 & & & & & $\mathrm{H}$ & $\mathrm{N}$ & $\mathrm{Pi}$ & Ane \\
\hline Ageratum conyzoides $\mathrm{L}$. & 115 & 159 & 127 & 126 & 98 & 129 & 172 & 88 & 79 & 123 & $\mathrm{H}$ & $\mathrm{N}$ & $\mathrm{Pi}$ & Zoo \\
\hline Conyza canadensis (L.) Cronquist & 11 & 15 & 18 & 21 & 31 & 33 & 17 & 17 & 33 & 17 & $\mathrm{H}$ & $\mathrm{E}$ & $\mathrm{Pi}$ & Ane \\
\hline Emilia sonchifolia (L.) DC. & & 3 & & & & & & & 3 & 3 & $\mathrm{H}$ & $\mathrm{N}$ & $\mathrm{Nc}$ & Ane \\
\hline Galinsoga parviflora Cav. & 3 & 1 & 2 & 1 & 15 & 9 & 6 & & 25 & 1 & $\mathrm{H}$ & $\mathrm{E}$ & $\mathrm{Pi}$ & Ane \\
\hline Galinsoga quadriradiata Ruiz \& Pav. & & & & 12 & & 3 & & & & & $\mathrm{H}$ & $\mathrm{E}$ & $\mathrm{Pi}$ & Ane \\
\hline Gnaphalium pensylvanicum Willd & & 4 & 5 & & 2 & 2 & 1 & 6 & & & $\mathrm{H}$ & $\mathrm{N}$ & ES & Ane \\
\hline Gnaphalium purpureum L. & 32 & & 2 & 4 & & 11 & & & & 2 & $\mathrm{H}$ & $\mathrm{N}$ & ES & Ane \\
\hline Gnaphalium spicatum Mill. & 1 & 1 & 1 & 4 & 15 & & & & & & $\mathrm{H}$ & $\mathrm{N}$ & ES & Ane \\
\hline Sonchus oleraceus L. & & 2 & & & & 3 & & & 3 & & $\mathrm{H}$ & $\mathrm{N}$ & $\mathrm{Pi}$ & Ane \\
\hline Vernonanthura diffusa (Less.) H. Rob. & 8 & 9 & 12 & 5 & 12 & 15 & 15 & & 6 & 32 & $\mathrm{~T}$ & $\mathrm{~N}$ & $\mathrm{Pi}$ & Ane \\
\hline $\begin{array}{l}\text { Vernonanthura phosphorica (Vell.) H. Rob. } \\
\text { Begoniaceae }\end{array}$ & & & 3 & & & & 2 & & 21 & & $\mathrm{~T}$ & $\mathrm{~N}$ & $\mathrm{Pi}$ & Ane \\
\hline Begonia cucullata Willd. & & & & & & & & 70 & & & $\mathrm{H}$ & $\mathrm{N}$ & $\mathrm{Pi}$ & Ane \\
\hline Brassicaceae & & & & & & & & & & & & & & \\
\hline $\begin{array}{l}\text { Lepidium virginicum } \mathrm{L} \text {. } \\
\text { Cannabaceae }\end{array}$ & 5 & 6 & 8 & 21 & 10 & 25 & 8 & 1 & 10 & 9 & $\mathrm{H}$ & E & $\mathrm{Pi}$ & $\mathrm{Nc}$ \\
\hline $\begin{array}{l}\text { Trema micrantha }(\mathrm{L} .) \text { Blume } \\
\text { Commelinaceae }\end{array}$ & 9 & 26 & 5 & & 10 & & & 3 & 121 & 223 & $\mathrm{~T}$ & $\mathrm{~N}$ & $\mathrm{Pi}$ & Zoo \\
\hline
\end{tabular}

Where: $\mathrm{LF}=$ Life Form; OR= Origin; $\mathrm{SC}=$ Successional Category; $\mathrm{DS}=$ Dispersal Syndrome; $\mathrm{H}=\mathrm{Herb} ; \mathrm{B} \mathrm{S}=\mathrm{Shrub} ; \mathrm{T}=\mathrm{Tree} ; \mathrm{V}=\mathrm{Vine} ; \mathrm{N}=\mathrm{Native} ; \mathrm{E}=\mathrm{Exotic} ; \mathrm{P}=$ Pioneer; ES= Early Secondary; LS= Late Secondary; Nc= Not Classified; Ane= Anemochory; Aut= Autochory; Zoo= Zoochory.

In addition, it can be observed that in the plot where the lowest percentage of canopy coverage was found (plot 3), there was a higher presence of Ageratum conyzoides L. (29.6\%); Phyllanthus tenellus Roxb (18.7\%) and Urochloa decumbens Stapf. (6.3\%), indicating a tendency for the establishment of the

Table 2 - Values of Canopy Openness (\%Cnpy Open) and Leaf Area Index (LAI) for each plot in the study area.

Tabela 2 - Valores de abertura de dossel (\% Cnpy Open) e indice de área foliar (LAI) para cada parcela da área estudada.

\begin{tabular}{ccc}
\hline Plots & \% Cnpy Open & LAI 4Ring \\
\hline 1 & 25.1 & 2.03 \\
2 & 16.44 & 2.31 \\
3 & 73.56 & 0.16 \\
4 & 40.48 & 1.05 \\
5 & 60.68 & 0.6 \\
6 & 27.74 & 1.77 \\
7 & 61.55 & 0.55 \\
8 & 15.64 & 2.45 \\
9 & 9.89 & 3.14 \\
10 & 15.48 & 2.95 \\
\hline
\end{tabular}

species according to the light incidence and specific conditions of areas with low canopy coverage.

On the other hand, in some plots with a greater canopy coverage (plots 8,9 and 10), there was a high presence of Trema micrantha (L.) Blume in the seed bank (except in plot 8), which represented $21 \%$ and $32.9 \%$ of the total seeds found in plots 8 and 9 , showing spatial grouping of this species in the area, high adaptability to these conditions (degraded), longevity/viability in the soil seed bank and high dispersibility (Martins et al. 2018b). Hence, Trema micrantha (L.) Blume is part of a seed bank that may guarantee further resilience of the area in case of future disturbances that may occur since, in this area, there are several adult individuals producing seeds and dispersing their propagules.

However, the invasive grasses in the seed bank were detected even in those plots with more significant canopy cover, especially those of the genus Urochloa, which may remain viable in the soil for several 


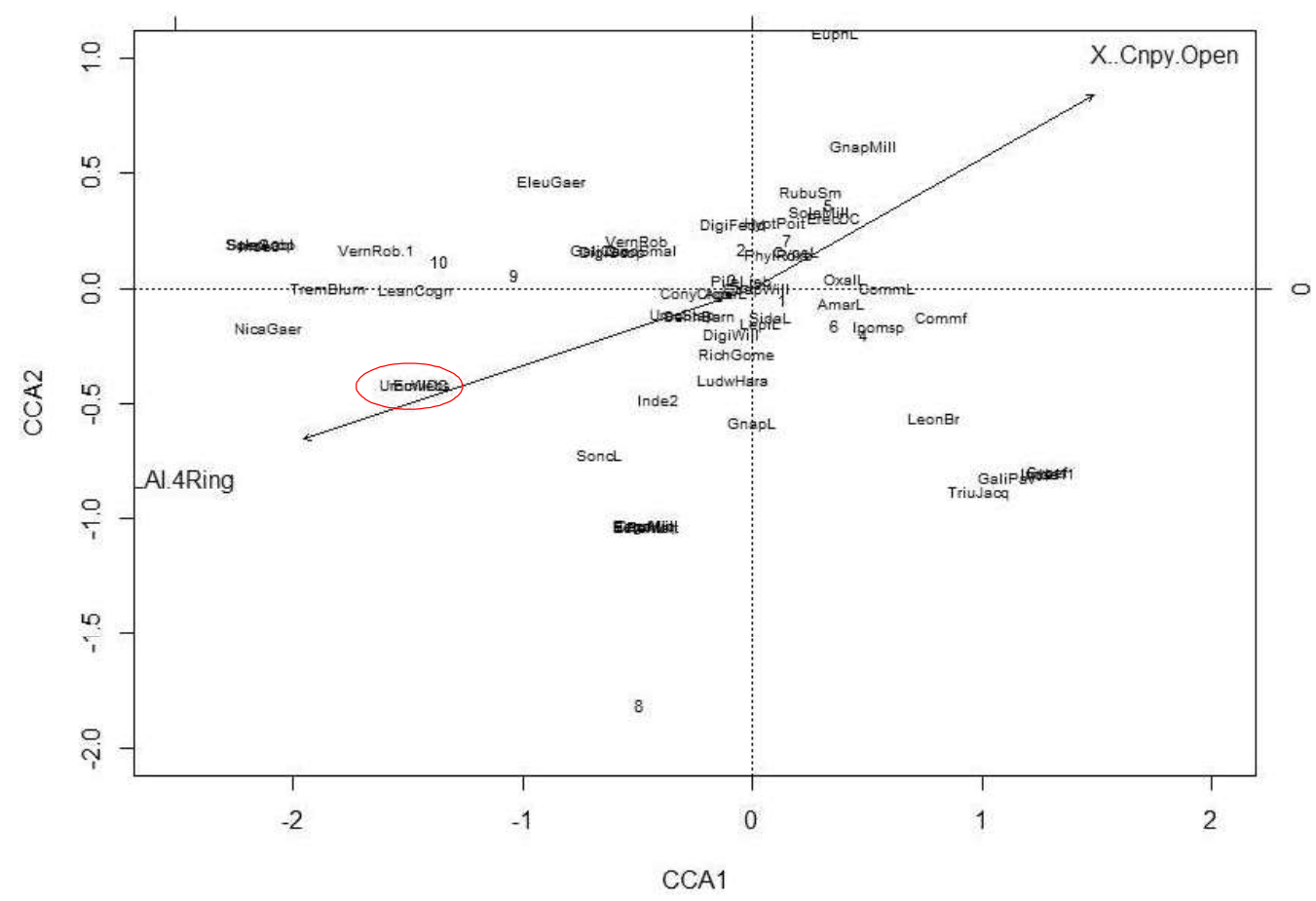

Figure 2 - Canonical correspondence analysis between the seed bank and the canopy cover variables.

Figura 2 - Análise de correspondência canônica entre o banco de sementes e as variáveis de cobertura de dossel.

years. The species of this genus accounted for $5.3 \%$ of the seeds in plot 9 and $3.8 \%$ in plot 10 , which is considered low, but may show that the invasive grass seed bank tends to be smaller in shaded environments, i.e., with higher canopy coverage.

These results point to the evaluation of the soil seed bank before its use for ecological restoration, such as seed bank transposition, which may possibly spread invasive species to other areas, as well as the need for medium and long term monitoring in degraded areas.

\section{DISCUSSION}

Through the evaluation and comparison of the diversity found in the seed bank of the study area, it is possible to verify an average diversity in the seed bank when compared to studies conducted in the region and in mining environments, as reported by Miranda Neto et al. (2014). In addition, the results were superior to those found in the studies by Costalonga (2006) and Braga et al. (2008), who also worked with the same life forms considered in this study and were carried out in Seasonal Semideciduous Forests in different conditions and stages of development and ciliary semideciduous broadleaved forest (Nóbrega et al., 2009).

On the other hand, higher values of diversity are found in the same forest typology of the study area, as observed by Peres et al. (2009) and Miranda Neto et al. (2014). Such fact may be related to the successional characteristic of the area, as well as the occurrence of changes/impacts (type, frequency, and intensity) in these areas.

The predominance of pioneer species found in the area's seed bank may also reveal the contribution of this successional group in the restoration process of altered areas, which may favor the establishment of tree species by the fact that it creates conditions that facilitate the entrance of species of more advanced successional categories, such as shading, improved soil conditions, higher soil moisture, relationship with fauna, among others (Martins, 2009).

Regarding the species found in the seed bank of the area, Trema micrantha (L.) Blume was found 
in large quantities, which is very important for the forest restoration process and is highly recommended for restoration of altered environments besides facilitating the gene flow of the fauna, since the species are dispersed by animals, which contributes to its ecological and environmental importance, especially for altered areas (Martins et al., 2018b).

As for the correlation analysis between canopy characteristics and seed bank, a strong correlation was observed between LAI and the presence of some herbs. This can be explained by the aggressive and invasive behavior mainly of some species of the genus Urochloa, which may inhibit the development of shrub and tree species, working as a physical "barrier" formed by the high population density of this grass, which prevents the germination and growth of most species and, consequently, maintains the canopy with small coverage and leaf area.

On the other hand, in the plots where there was more significant presence of shrub and tree species, that is, with higher canopy cover, a reduction was observed in the number of invasive herbs in the seed bank, thus demonstrating that canopy cover can directly influence the presence and viability of seeds of invasive herbaceous species, thereby controlling their development and dispersal.

In this sense, canopy cover has a positive effect on the control of invasive grasses due to shading, therefore decreasing the intensity of solar radiation that reaches the ground, which is not sufficient for the germination and development of these species. Moreover, with the larger canopy cover produced by shrub and tree species and provided there is no disturbance that radically alters the stand trajectory, the tendency is that these species will provide propagules and increase their densities over time due to adaptation to these environmental conditions, as well as the interaction with the regional fauna and flora, thus reducing the density of invasive species due to seed unviability (dormancy time/microorganisms activity) and increasing the diversity and density of native shrub and tree species in the area.

Therefore, interventions are necessary to increase the diversity of the area, which should be carried using tree species native to the region and with advanced successional category (late secondary and climax species), thus avoiding reestablishment of invasive grasses in the area. In addition, it is recommended to evaluate and monitor the seed bank at different times and also to use forest species with zoochoric dispersal syndrome, which can assist in the propagation of propagules among neighboring native fragments and, consequently, increase the gene flow of fauna, thus accelerating the ecological restoration process of the environment.

Moreover, due to the variation that exists between the different plots of the restoration area, the use of different restoration techniques should be proposed and defined according to the specific characteristics verified in each environment, the associated costs and efficiency in the results produced.

\section{CONCLUSION}

Given the presence of the amount greater than $23 \%$ of exotic species contained in the area's seed bank, as well as the current condition of coverage of specific plots of the area under the invasion of grasses, interventions to control these species become necessary. This is because any disturbances that may occur in this area and produce an opening in the canopy promote the colonization and dominance by these species, thus impairing the successional process and restoration of the area.

In addition, the small presence of early and late secondary succession species in the area's seed bank justifies the need for interventions to enrich the diversity of species of more advanced stages of succession, so that, along with the use of other techniques, ecological functions of this area can be restored.

However, despite the need for interventions aimed at controlling invasive grasses in some plots, the area is generally evolving from a successional and ecological point of view when the technique that was used (natural regeneration) is considered since no interventions were made to assist the forest succession process in the area. Therefore, the topographic reconformation and soil preparation techniques adopted by the company allowed the natural regeneration of the area. This can be verified by the presence of shrub and tree species of higher successional categories in the area (late secondary), which indicates progress in the restoration process of this environment.

Revista Árvore 2019;43(4):e430403 
In this sense, to maximize the chances of restoration of the area and in the shortest time as possible, it is necessary to define and use techniques to accelerate the restoration process, enrich local diversity and attract fauna to achieve environmental sustainability of the area. Thus, it is recommended to use native species seedlings and/or planting in diversity nuclei with the use of early and late secondary species of shrub and tree life forms to enrich the existing plant community and stimulate the process of restoration of the area.

\section{ACKNOWLEDGMENTS}

The authors thank the Coordination for the Improvement of Higher Education Personnel (CAPES - Coordenação de Aperfeiçoamento de Pessoal de Nível Superior) for supporting this study through the scholarship and Aluminiun Brazilian Company (CBA -Companhia Brasileira de Alumínio) for the financial support.

\section{REFERENCES}

Associação Pró-Gestão das Águas da Bacia Hidrográfica do Rio Paraíba do Sul - AGEVAP. Plano municipal de saneamento básico. São Sebastião da Vargem Alegre, MG: 2013; 234p.

Braga AJT, Griffith JJ, Paiva HN, Meire Neto JAA. Composição do banco de sementes de uma floresta Semidecidual secundária considerando o seu potencial de uso para recuperação ambiental. Revista Árvore. 2008; 32(6):1089-1098. doi: dx.doi. org/10.1590/S0100-67622008000600014.

Chianucci F, Cutini A. Estimation of canopy properties in deciduous forests with digital hemispherical and cover photography. Agricultural and Forest Meteorology. 2013; 168:130-139.

Costalonga SR, Reis GG, Reis MGF, Silva AF, Borges EEL, Guimarães FP. Florística do banco de sementes do solo em áreas contíguas de pastagem degradada, plantio de eucalipto e floresta em Paula Cândido, MG. Revista Floresta. 2006; 36(2):239250. doi: http://dx.doi.org/10.5380/rf.v36i2.6455

Coutts SR, van Klinken RD, Yokomizo H, Buckley YM. What are the key drivers of spread in invasive plants: dispersal, demography or landscape: and how can we use this knowledge to aid management?. Biological invasions. 2011;13(7):1649-1661. doi: doi.org/10.1007/ s10530-010-9922-5.

Cumming GS, Barnes G, Perz S, Schmink M, Sieving KE, Southworth J et al. An exploratory framework for the empirical measurement of resilience. Ecosystems. 2005; 8(8):975-987.

Embrapa Solos. Sistema brasileiro de classificação de solos. Centro Nacional de Pesquisa de Solos: Rio de Janeiro; 2013.

Frazer GW, Canham CD, Lertzman KP. Gap Light Analyzer (GLA), Version 2.0: Imaging software to extract canopy structure and gap light transmission indices from true-colour fisheye photographs, users manual and program documentation. Simon Fraser University, Burnaby, British Columbia, and the Institute of Ecosystem Studies, Millbrook. New York.1999; v.36.

Gaudio N, Gendre X, Saudreau M, Seigner V, Balandier P. Impact of tree canopy on thermal and radiative microclimates in a mixed temperate forest: A new statistical method to analyse hourly temporal dynamics. Agricultural and Forest Meteorology. 2017;237-238:71-79.doi: doi.org/10.1016/j. agrformet.2017.02.010.

Hall SL, Barton CD, Baskin CC. Topsoil Seed Bank of an Oak-Hickory Forest in Eastern Kentucky as a Restoration Tool on Surface Mines. Restoration Ecology. 2010;18(6):834-842. doi: doi.org/10.1111/ j.1526-100X.2008.00509.x.

Hyatt LA, Casper BB. Seed bank formation during early secondary succession in a temperate deciduous forest. Journal of Ecology. 2001;88(3):516-527. doi: doi.org/10.1046/j.13652745.2000.00465.x

Instituto Brasileiro de Geografia e Estatística IBGE. Manual Técnico da Vegetação Brasileira. 2nd ed. Manuais Técnicos em Geociências. Rio de Janeiro; 2012.

Köppen W. Climatologia: con un estudio de los climas de la tierra. Fondo de Cultura Econômica. México. 1948; 479p.

\section{Revista Árvore 2019;43(4):e430403}


Leblanc SG, Chen JM. A practical scheme for correcting multiple scattering effects on optical LAI measurements. Agricultural and Forest Meteorology. 2001;11(2):125-139. doi: doi. org/10.1016/S0168-1923(01)00284-2.

Linhares CA, Ponzoni FJ, Shimabukuro YE. Relação entre volume de madeira e Índice de Área Foliar em um povoamento de Pinus spp.: estudo de caso. Revista Árvore. 2000:24(1):47-54.

Lu ZJ, Li LF, Jiang MX, Huang HD, Bao DC. Can the soil seed bank contribute to revegetation of the drawdown zone in the Three Gorges Reservoir Region?. Plant Ecol. 2010; 209(1):153-165. doi:10.1007/s11258-010-9732-y.

Macfarlane C, Coote M, White D, Adams MA. Photographic exposure affects indirect estimation of leaf area in plantations of Eucalyptus globulus Labill. Agricultural and Forest Meteorology. 2000;100(2):155-168. doi: 10.1016/S01681923(99)00139-2.

Martins SV, Almeida DP, Fernandes LV, Ribeiro TM. Banco de sementes como indicador de restauração de uma área degradada por mineração de caulim em Brás Pires, MG. Revista Árvore. 2008;32(6):1081-1088. doi: dx.doi.org/10.1590/ S0100-67622008000600013.

Martins SV, Balestrin D, Lopes AT. Trema micrantha (L.) Blume, espécie chave na restauração de áreas degradadas. MG Biota. 2018b;10(4):61-68.

Martins SV, Borges EE, Silva KA. O banco de sementes do solo e sua utilização como bioindicador de restauração ecológica: In: Martins SV. (Ed.) Restauração ecológica de ecossistemas degradados. Viçosa: Editora UFV; 2015. p. 293-330.

Martins SV. Alternative Forest Restoration Techniques. In: Viana H. New Perspectives in Forest Science. chapter 7. IntechOpen; 2018a. p.131-148. Available on: https://www.intechopen. com/books/new-perspectives-in-forest-science/ alternative-forest-restoration-techniques Accessed: 06 July 2018.

Martins SV. Recuperação de áreas degradadas: ações em áreas de preservação permanente, voçorocas, taludes rodoviários e de mineração.
Viçosa, MG: Aprenda Fácil; 2009. 270p.

Matlaga DP, Snyder RK, Horvitz CC. Dispersal of Goeppertia marantifolia clonal offspring increases with greater canopy openness and larger plant size. Journal of Tropical Ecology. 2017;33(2):107-113.

Miranda Neto A, Martins SV, Silva KA, Gleriani JM. Banco de sementes do solo e serapilheira acumulada em Floresta restaurada. Revista Árvore. 2014;38(4):609-620. doi: dx.doi.org/10.1590/ S0100-67622014000400004.

Nóbrega AMF, Valeri SV, Paula RC, Pavani MCMD, Silva SA. Banco de sementes de remanescentes naturais e de áreas reflorestadas em uma várzea do rio Mogi-Guaçu - SP. Revista Árvore. 2009;33(3):403-411.doi: dx.doi. org/10.1590/S0100-67622009000300002.

Oksanen J, Blanchet FG, Friendly M, Kindt R, Legendre P, Mcglinn D, et al. Package 'vegan'. Available on: https://cran.r-project.org/web/ packages/vegan/vegan.pdf Accessed: 26 July 2016.

Ooi MKJ. Seed bank persistence and climate change. Seed Science Research. Cambridge University Press. 2012; 22(1):53-60. doi: doi. org/10.1017/S0960258511000407.

Peres MA, Pinto LVA, Loures L. Avaliação dos bancos de sementes do solo de fragmentos florestais de mata estacional semidecidual clímax e secundária e seu potencial em recuperar áreas degradadas. Revista agrogeoambiental. 2009; 1(2):121-133. doi:10.18406/2316-1817v1n2200984

Shepherd GJ. Fitopac 2.1 - Campinas, Brasil. Departamento de Botânica, Universidade Estadual de Campinas; 2010.

Simpson RL, Leck MA, Parker VT. Seed banks: general concepts and methodological issues. In: Leck MA, Parker VT, Sipmson, RL (Eds.). Ecology of soil seed banks. London: Academic. 1989; p.3-8.

Song X, Hogan JA, Lin L, Wen H, Cao M, Yang J. Canopy openness and topographic habitat drive tree seedling recruitment after snow damage in an old-growth subtropical forest. Forest Ecology and Management. 2018; 429:493-502. doi: doi.

Revista Árvore 2019;43(4):e430403 
org/10.1016/j.foreco.2018.07.038.

Ter Braak CJF, Prentice IC. A theory of gradient analysis. Advances in Ecological Research. 1988; 18(1):271-317. doi: 10.1016/S00652504(08)60183-X.

Villa Nova NA, Moreira PR, Pereira AB. Eficiência de captura de energia solar por dosséis de Eucalyptus pellita F. Muell sob várias densidades de plantio. Revista Brasileira de Agrometeorologia. 2003;11(2):269-274.

Von Arx G, Dobbertin M, Rebetez M. Spatiotemporal effects of forest canopy on understory microclimate in a long-term experiment in
Switzerland. Agricultural and Forest Meteorology. 2012;166-167:144-155. doi: doi.org/10.1016/j. agrformet.2012.07.018.

Woodgate W, Jones SD, Suarez L, Hill MJ, Armston JD, Wilkes $\mathrm{P}$ et al. Understanding the variability in ground-based methods for retrieving canopy openness, gap fraction, and leaf area index in diverse forest systems. Agricultural and Forest Meteorology. 2015;205:83-95.doi: doi. org/10.1016/j.agrformet.2015.02.012.

Xavier AC, Vettorazzi CA. Leaf area index of ground covers in a subtropical watershed. Scientia Agricola. 2003;60(3):425-431. doi: dx.doi. org/10.1590/S0103-90162003000300002. 